\title{
1 Trend prediction of COVID-19 based on ARIMA model in mainland
}

2

3

4

5 a, College of Resources and Environment Sciences, Xinjiang University, Urumqi 830046, China

6

$7 \quad$ Urumqi 830046, China

\section{of China}

b, Key Laboratory of City Intellectualizing and Environment Modelling, Xinjiang University,
9

\section{Highlights:}

1.We predicted future COVID-19 occurrences in mainland of China based on ARIMA model.

2. We validated the model based on the previous outbreak data with actual data for June, 2020.

3. The measures taken by the government have contained spread of the epidemic

4. The combination of multiple models may improve the robustness of the model

Abstract: The ongoing pandemic of COVID-19 has aroused widespread concern around the world and poses a severe threat to public health worldwide. In this paper, the autoregressive integrated moving average (ARIMA) model was used to predict the epidemic trend of COVID-19 in mainland of China. We collected the cumulative cases, cumulative deaths, and cumulative recovery in mainland of China from January 20 to June 30, 2020, and divided the data into experimental group and test group. The ARIMA model was fitted with the experimental group

\footnotetext{
${ }^{1}$ Chuqiao Hana and Xifeng Ju are co-first authors of the article.

*Corresponding author at: College of Resources \& Environment Science, Xinjiang University, Urumqi 830046, China; Institute of Arid Ecology and Environment, Xinjiang University, Urumqi 830046, China; Key Laboratory for Oasis Ecology, Xinjiang University, Urumqi 830046, China.

E-mail address: zheng_jianghua@126.com (J. Zheng).
} 
21 data, and the optimal model was selected for prediction analysis. The predicted data were

22 compared with the test group. The average relative errors of actual cumulative cases, deaths,

23 recovery and predicted values in each province are between $-22.32 \%-22.66 \%,-9.52 \%-0.08 \%$,

$24-8.84 \%-1.16$, the results of the comprehensive experimental group and test group show The error

25 of fitting and prediction is small, the degree of fitting is good, the model supports and is suitable

26 for the prediction of the epidemic situation, which has practical guiding significance for the

27 prevention and control of the epidemic situation.

28 Keywords: ARIMA model; COVID-19; optimal model; prediction 


\section{Introduction} aspects [2]. In order to effectively suppress the spread of COVID-19, the Chinese government has successively announced the launch of a first-level response mechanism for major public health

of prevention and control is getting better, the global situation is still not optimistic.

ARIMA model considers the law that the historical data of the research object itself changes

with time, and uses this to predict future values, that is, to replace various influence factors with time. At present, the advantage of ARIMA model in predicting infectious diseases has been confirmed in many studies[4-5].

This study is based on the autoregressive integrated moving average model to predict the cumulative cases, cumulative deaths, and cumulative recovery of COVID-19 in mainland of China, and select the most appropriate model to simulate the epidemic pattern by simulating multiple models. A preliminary explanation is given to evaluate the effects of the epidemic prevention and control measures at this stage.

\section{Data and Methods}

\subsection{Data Sources}

The COVID-19 case data comes from the National and local health and construction 
51 commission daily information release (https://ncov.dxy.cn/). We collected the cumulative cases, deaths, recovery in mainland of China from January 20, 2020 to June 30, 2020.

\subsection{Methods}

ARMA model is a stationary time series model, but COVID-19 daily cases, deaths and recovery changes with volatility, uncertainty, is a non-stationary random process, so this article introduces the difference operator I (The original non-stationary time series can be improved into a stationary time series after d-order difference), establish the COVID-19 cumulative cases, deaths, and recovery trend prediction ARIMA model. In recent years, the ARIMA model has become one

60

61

of the most commonly used methods in the prediction of many epidemics. This method is particularly suitable for short-term prediction of infectious diseases, and its prediction accuracy has been widely recognized, at the same time, it can also provide effective help for disease prevention and policy-making[6].

ARIMA model is composed of autoregressive model (AR model $(\mathrm{P})$ ), moving average model( MA model (q) ) and difference operator I (d), where p, d and q are autoregressive order, difference order and moving average order of time series[7]. The expression of the p-order AR model is as follows:

$$
\mathrm{Y}_{\mathrm{t}}=\mathrm{C}_{1}+\alpha_{1} \mathrm{Y}_{\mathrm{t}-1}+\alpha_{2} \mathrm{Y}_{\mathrm{t}-2}+\ldots+\alpha_{\mathrm{p}} \mathrm{Y}_{\mathrm{t}-\mathrm{p}}+\mathrm{e}_{\mathrm{t}}
$$

Where $\alpha \mathrm{i}(\mathrm{i}=1,2, \ldots, \mathrm{p})$ is the AR model coefficient, $\mathrm{e}_{\mathrm{t}}$ is the random interference term, and $\mathrm{C}_{1}$ is the constant.

The mathematical expression of the q order MA model is:

$$
\mathrm{Y}_{\mathrm{t}}=\mathrm{G}(\mathrm{B}) \mathrm{e}_{\mathrm{t}}+\mathrm{c} 2
$$




$$
G(B)=\left(1-\beta_{1} B-\beta_{2} B^{2}-\ldots-\beta_{q} B^{q}\right)
$$

Where $\beta_{\mathrm{j}}(\mathrm{j}=1,2, \ldots, \mathrm{q})$ is the MA model coefficient, $\mathrm{e}_{\mathrm{t}}$ is the random interference term, and $\mathrm{c}_{2}$ is the constant.

Combining the time series after the difference of order $d$, the final expression of the ARIMA model is:

$$
F(x)=c+\alpha_{1} X_{t-1}+\alpha_{2} X_{t-2}+\ldots+\alpha_{p} X_{t-p}+\beta_{1} e_{t-1}+\ldots+\beta_{q} e_{t-q}
$$

Where $\alpha$ represents the coefficient of $\mathrm{AR}, \beta$ represents the coefficient of MA, and $\mathrm{c}$ is the constant term.

\section{ARMA model construction ( Fig.1 The flowchart of ARIMA modelFig.1 ) :}

(1) Data difference: the collected COVID-19 data are divided for several times to make it stable, and then the autocorrelation and partial autocorrelation tests are performed on the differential data.

(2) The choice of modeling parameters: according to an information criterion (AIC) and Bayesian information criterions (BIC), combing with the autocorrelation function (ACF) and partial autocorrelation function (PACF) of the residual sequence to determine the order of the model, and finally select the model with the highest fitting degree[8].

$$
\mathrm{AIC}=-2 \ln (\mathrm{L})+2 \mathrm{~m}
$$

$$
\mathrm{BIC}=-2 \ln (\mathrm{L})+\operatorname{mln}(\mathrm{n})
$$

Where: $\mathrm{L}$ is the maximum likelihood function of the model, $\mathrm{m}$ is the number of estimated parameters, and $\mathrm{n}$ is the sample size.

(3) Verify the reliability of the model: we use the model to predict the cumulative cases, deaths, recovery in Chinese provinces (excluding Hong Kong, Macao, and Taiwan) from June 


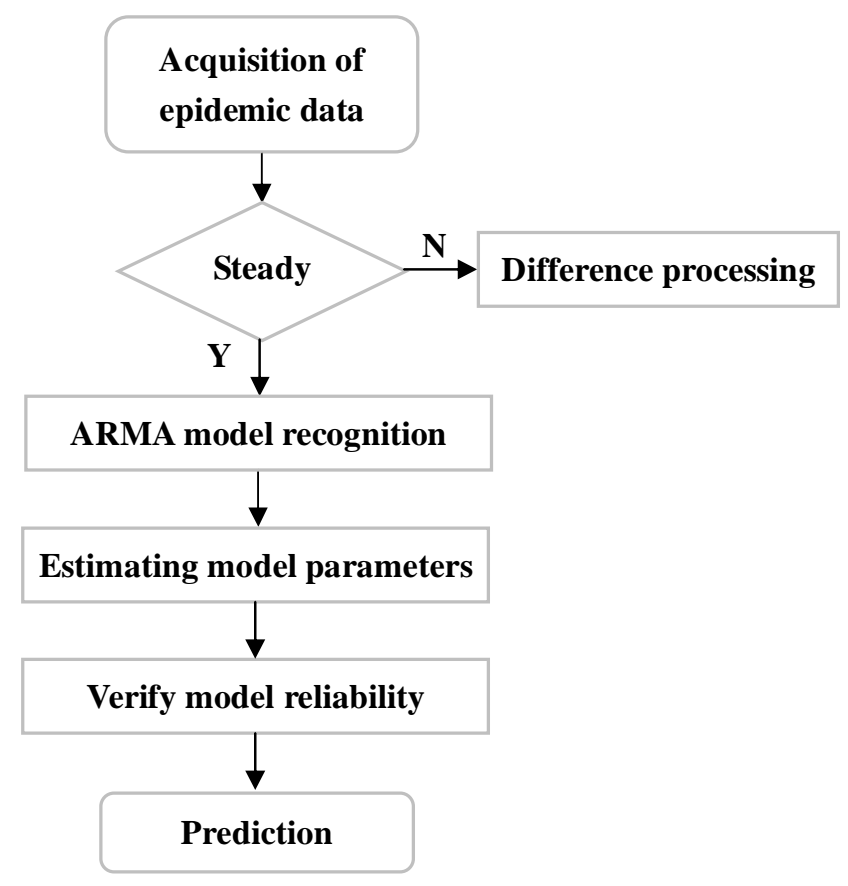

Fig.1 The flowchart of ARIMA model

\section{Results}

We build a model based on the cumulative cases, deaths, and recovery data in mainland of China from January 20 to May 30, 2020. Here we take Hubei Province as an example to describe the recognition process of the model.

First, we build the original time series figure (Fig.2), from the figure, we can see that the initial outbreak of COVID-19 increased exponentially. The Chinese government took timely measures to control the epidemic. It can be seen from Fig. 2 that the original data time series are not stationary, so we need to carry out first-order differential processing on the original data. The processed time series is shown in Fig.3. Since the time series in Fig.3 is still unstable, we need to 
111 is determined.

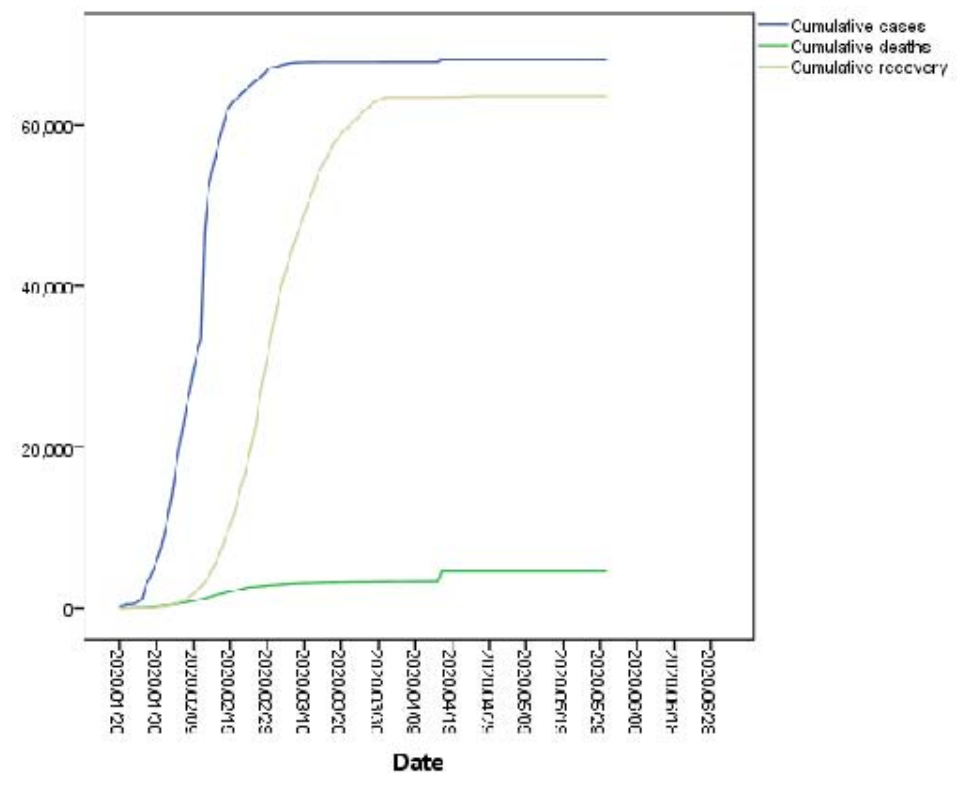

112

Fig.2 The cumulative cases, deaths, recovery original time series figure

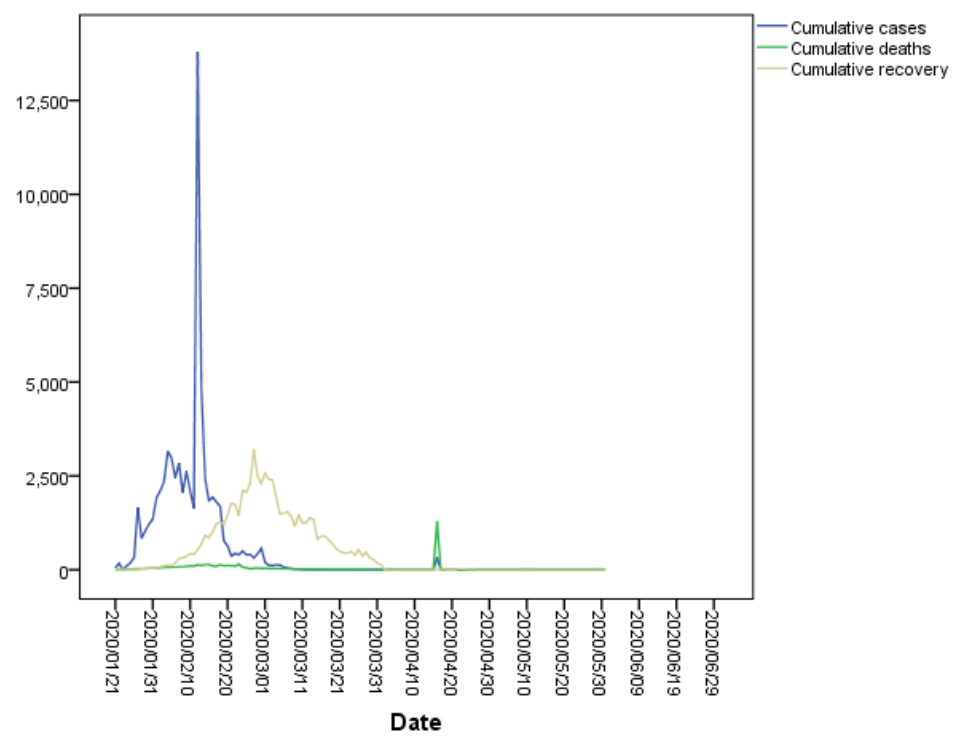




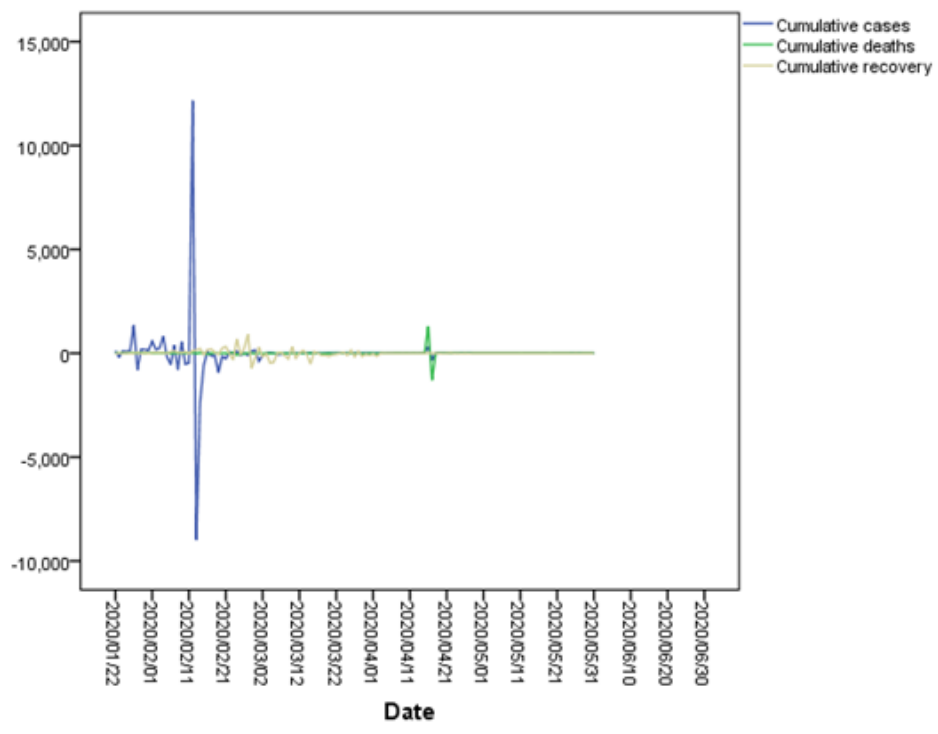

Fig.4 Second-order difference processing time series figure $(\mathrm{d}=2)$ AIC and BIC values as the best model, and then verify the model.

127 indicating that there is no autocorrelation in the residual sequence. Then the model through the 
medRxiv preprint doi: https://doi.org/10.1101/2020.09.04.20188235; this version posted September 9, 2020. The copyright holder for this preprint (which was not certified by peer review) is the author/funder, who has granted medRxiv a license to display the preprint in perpetuity.

All rights reserved. No reuse allowed without permission.

130
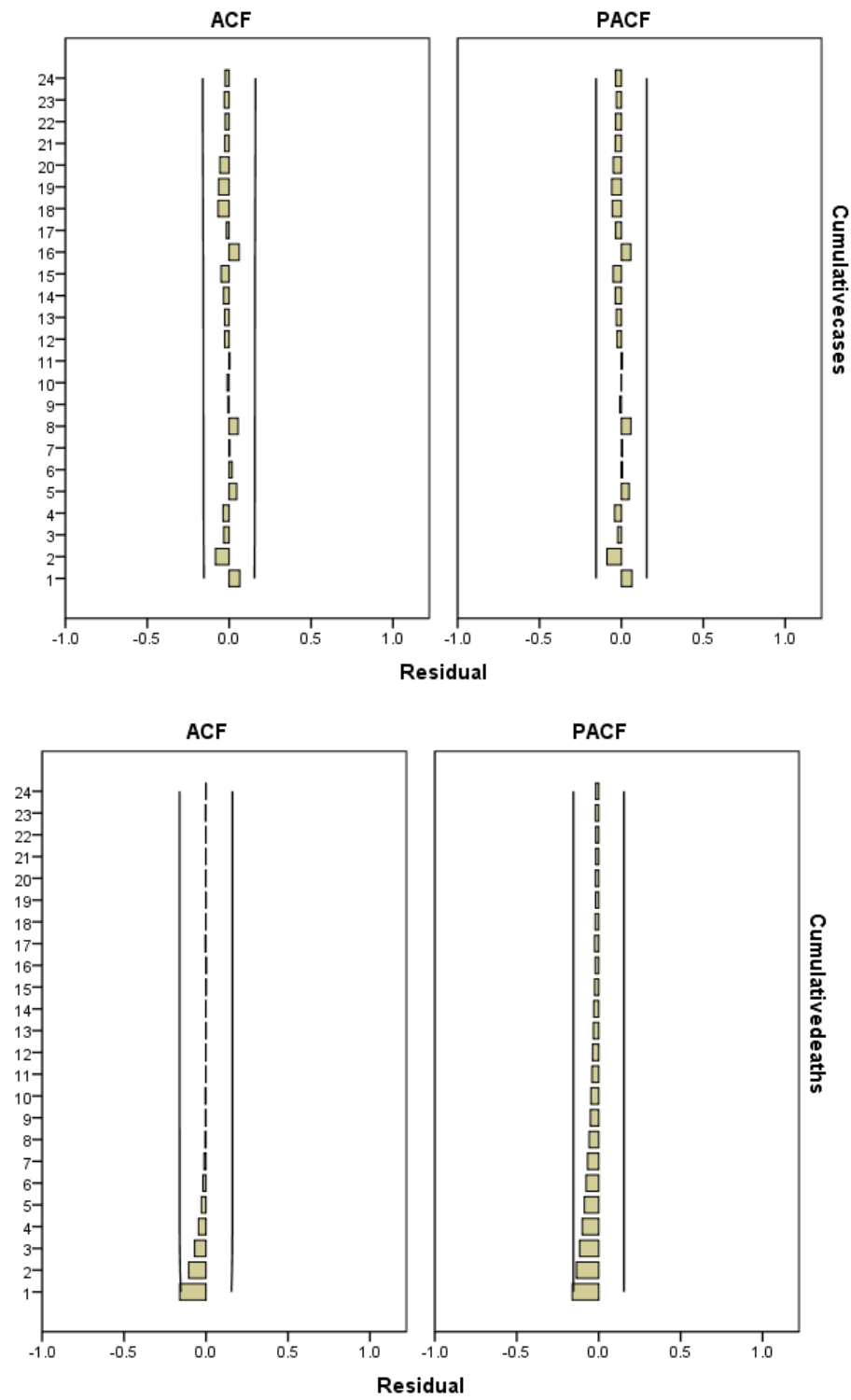

131 
132

\section{Table 1}

143 the average relative error table of actual cumulative cases, deaths, recovery and fitted values in each province

144 during January 20, 2020 to May 31, 2020

\begin{tabular}{lcccccc}
\hline & Cumulative & Cumulative & Cumulative & Cumulative & Cumulative & Cumulative \\
Province & & & & & \\
& cases model & cases & deaths model & deaths & recovery model & recovery \\
\hline
\end{tabular}

Model test and error analysis : We divided the data into experimental group (January 20 May 31, 2020) and test group (June 1 - June 30, 2020), First of all, we bring the data of the experimental group into the ARIMA model of the cumulative cases, deaths, recovery in each province, and calculate the average relative error between the actual number and the fitted value.

The results are shown in Table 1.
ACF PACF

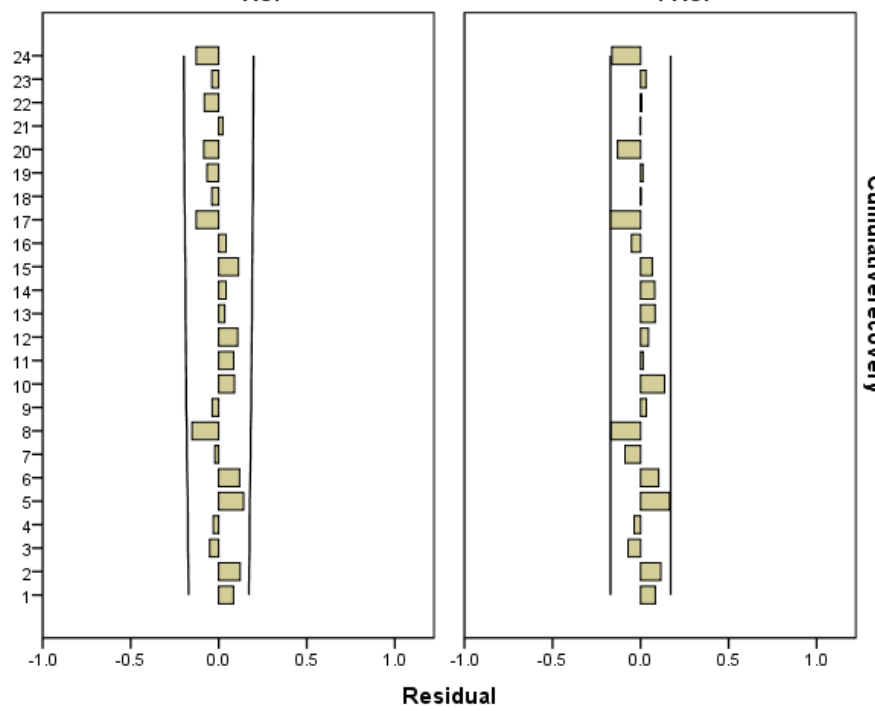

Fig.5 Residual sequence figure of ARIMA model for the cumulative cases, deaths, recovery in Hubei Province 
medRxiv preprint doi: https://doi.org/10.1101/2020.09.04.20188235; this version posted September 9, 2020. The copyright holder for this preprint (which was not certified by peer review) is the author/funder, who has granted medRxiv a license to display the preprint in perpetuity.

All rights reserved. No reuse allowed without permission.

\begin{tabular}{|c|c|c|c|c|c|c|}
\hline & type & average & type & average & type & average \\
\hline & & relative & & relative & & relative \\
\hline & & error & & error & & error \\
\hline Beijing & $\operatorname{ARIMA}(0,2,1)$ & $0.60 \%$ & $\operatorname{ARIMA}(1,2,17)$ & $1.92 \%$ & $\operatorname{ARIMA}(0,2,1)$ & $3.20 \%$ \\
\hline Shanghai & $\operatorname{ARIMA}(2,2,1)$ & $0.68 \%$ & $\operatorname{ARIMA}(0,1,0)$ & $1.94 \%$ & $\operatorname{ARIMA}(0,2,4)$ & $3.01 \%$ \\
\hline Gansu & $\operatorname{ARIMA}(1,1,0)$ & $0.92 \%$ & $\operatorname{ARIMA}(0,1,2)$ & $0.00 \%$ & $\operatorname{ARIMA}(0,2,1)$ & $0.71 \%$ \\
\hline Sichuan & $\operatorname{ARIMA}(0,2,0)$ & $1.75 \%$ & $\operatorname{ARIMA}(0,1,0)$ & $1.63 \%$ & $\operatorname{ARIMA}(0,2,11)$ & $3.47 \%$ \\
\hline Hebei & $\operatorname{ARIMA}(1,2,8)$ & $2.09 \%$ & $\operatorname{ARIMA}(0,1,4)$ & $1.24 \%$ & $\operatorname{ARIMA}(0,2,7)$ & $0.79 \%$ \\
\hline Shaanxi & $\operatorname{ARIMA}(3,2,0)$ & $1.78 \%$ & $\operatorname{ARIMA}(0,1,5)$ & $1.49 \%$ & $\operatorname{ARIMA}(0,2,1)$ & $1.65 \%$ \\
\hline Guangdong & $\operatorname{ARIMA}(0,2,1)$ & $19.64 \%$ & $\operatorname{ARIMA}(6,1,0)$ & $2.23 \%$ & $\operatorname{ARIMA}(2,2,2)$ & $1.63 \%$ \\
\hline Liaoning & $\operatorname{ARIMA}(2,2,0)$ & $1.12 \%$ & $\operatorname{ARIMA}(0,1,0)$ & $0.93 \%$ & $\operatorname{ARIMA}(1,2,2)$ & $2.36 \%$ \\
\hline Chongqing & $\operatorname{ARIMA}(1,2,0)$ & $1.01 \%$ & $\operatorname{ARIMA}(0,2,2)$ & $0.65 \%$ & $\operatorname{ARIMA}(2,2,2)$ & $1.16 \%$ \\
\hline Fujian & $\operatorname{ARIMA}(1,2,0)$ & $1.14 \%$ & $\operatorname{ARIMA}(0,1,0)$ & $0.00 \%$ & $\operatorname{ARIMA}(0,2,1)$ & $2.58 \%$ \\
\hline Tianjin & $\operatorname{ARIMA}(0,2,5)$ & $0.48 \%$ & $\operatorname{ARIMA}(0,2,1)$ & $1.29 \%$ & $\operatorname{ARIMA}(0,2,1)$ & $3.04 \%$ \\
\hline Jiangsu & $\operatorname{ARIMA}(1,2,0)$ & $2.15 \%$ & $\operatorname{ARIMA}(0,0,0)$ & $*$ & $\operatorname{ARIMA}(0,2,13)$ & $2.61 \%$ \\
\hline Hubei & $\operatorname{ARIMA}(0,2,1)$ & $1.99 \%$ & $\operatorname{ARIMA}(1,2,1)$ & $1.69 \%$ & $\operatorname{ARIMA}(1,2,4)$ & $0.98 \%$ \\
\hline Zhejiang & $\operatorname{ARIMA}(3,2,0)$ & $0.51 \%$ & $\operatorname{ARIMA}(0,1,0)$ & $0.00 \%$ & $\operatorname{ARIMA}(0,2,7)$ & $2.64 \%$ \\
\hline Henan & $\operatorname{ARIMA}(2,2,0)$ & $2.80 \%$ & $\operatorname{ARIMA}(1,2,2)$ & $1.69 \%$ & $\operatorname{ARIMA}(2,2,2)$ & $1.89 \%$ \\
\hline Hainan & $\operatorname{ARIMA}(0,2,1)$ & $0.62 \%$ & $\operatorname{ARIMA}(3,1,11)$ & $1.83 \%$ & $\operatorname{ARIMA}(3,2,0)$ & $3.12 \%$ \\
\hline Heilongjiang & $\operatorname{ARIMA}(0,2,1)$ & $1.30 \%$ & $\operatorname{ARIMA}(0,2,7)$ & $1.39 \%$ & $\operatorname{ARIMA}(1,2,0)$ & $1.21 \%$ \\
\hline Jilin & $\operatorname{ARIMA}(0,2,1)$ & $2.43 \%$ & $\operatorname{ARIMA}(0,1,0)$ & $0.87 \%$ & $\operatorname{ARIMA}(0,2,2)$ & $2.23 \%$ \\
\hline Hunan & $\operatorname{ARIMA}(0,2,1)$ & $2.01 \%$ & $\operatorname{ARIMA}(0,1,2)$ & $1.62 \%$ & $\operatorname{ARIMA}(0,2,1)$ & $1.86 \%$ \\
\hline
\end{tabular}


medRxiv preprint doi: https://doi.org/10.1101/2020.09.04.20188235; this version posted September 9, 2020. The copyright holder for this preprint (which was not certified by peer review) is the author/funder, who has granted medRxiv a license to display the preprint in perpetuity.

All rights reserved. No reuse allowed without permission.

\begin{tabular}{|c|c|c|c|c|c|c|}
\hline Shandong & $\operatorname{ARIMA}(1,2,0)$ & $2.00 \%$ & $\operatorname{ARIMA}(0,1,6)$ & $2.21 \%$ & $\operatorname{ARIMA}(4,2,0)$ & $3.28 \%$ \\
\hline Tibet & $\operatorname{ARIMA}(0,1,0)$ & $0.00 \%$ & $\operatorname{ARIMA}(0,0,0)$ & $*$ & $\operatorname{ARIMA}(0,1,0)$ & $0.00 \%$ \\
\hline Guangxi & $\operatorname{ARIMA}(0,2,8)$ & $1.41 \%$ & $\operatorname{ARIMA}(0,1,4)$ & $0.00 \%$ & $\operatorname{ARIMA}(0,2,3)$ & $2.06 \%$ \\
\hline Shanxi & $\operatorname{ARIMA}(6,2,0)$ & $0.79 \%$ & $\operatorname{ARIMA}(0,0,0)$ & $*$ & $\operatorname{ARIMA}(0,2,1)$ & $2.54 \%$ \\
\hline Ningxia & $\operatorname{ARIMA}(0,2,12)$ & $0.49 \%$ & $\operatorname{ARIMA}(0,0,0)$ & $*$ & $\operatorname{ARIMA}(2,2,1)$ & $4.13 \%$ \\
\hline Xinjiang & $\operatorname{ARIMA}(1,2,2)$ & $1.15 \%$ & $\operatorname{ARIMA}(0,1,9)$ & $1.38 \%$ & $\operatorname{ARIMA}(0,2,1)$ & $0.41 \%$ \\
\hline Jiangxi & $\operatorname{ARIMA}(0,2,5)$ & $2.23 \%$ & $\operatorname{ARIMA}(0,1,0)$ & $0.00 \%$ & $\operatorname{ARIMA}(0,2,3)$ & $0.85 \%$ \\
\hline Guizhou & $\operatorname{ARIMA}(1,2,7)$ & $0.80 \%$ & $\operatorname{ARIMA}(0,1,0)$ & $0.86 \%$ & $\operatorname{ARIMA}(0,2,1)$ & $2.79 \%$ \\
\hline Inner Mongolia & $\operatorname{ARIMA}(0,1,2)$ & $-1.23 \%$ & $\operatorname{ARIMA}(0,1,0)$ & $0.00 \%$ & $\operatorname{ARIMA}(1,1,1)$ & $-8.57 \%$ \\
\hline Anhui & $\operatorname{ARIMA}(1,2,0)$ & $3.82 \%$ & $\operatorname{ARIMA}(0,1,0)$ & $2.46 \%$ & $\operatorname{ARIMA}(0,2,10)$ & $1.37 \%$ \\
\hline Qinghai & $\operatorname{ARIMA}(0,1,6)$ & $-2.92 \%$ & $\operatorname{ARIMA}(0,0,0)$ & $*$ & $\operatorname{ARIMA}(0,2,6)$ & $0.00 \%$ \\
\hline Yunnan & $\operatorname{ARIMA}(1,2,0)$ & $2.23 \%$ & $\operatorname{ARIMA}(0,1,0)$ & $0.98 \%$ & $\operatorname{ARIMA}(0,2,6)$ & $0.59 \%$ \\
\hline
\end{tabular}

Note: * means that the cumulative death is 0 , which cannot be calculated.

147 It can be seen from Table 1 that the average relative error of the cumulative cases in each

148 province is between $-2.92 \%$ and $3.82 \%$ (except for Guangdong Province); the average relative

149 error of the cumulative cases in Guangdong Province is 19.64\%. By analyzing the data of

150 Guangdong Province, we found that on January 23, 2020, the actual cumulative cases were 26,

151 and the fitting value was 1 . This is mainly since at the early stage of the epidemic, the

152 transmission route of COVID-19 was not known, and the government did not take effective

153 measures, so the number of cases increased exponentially, which led to a large error at that time.

154 The average relative errors of cumulative deaths and recovery in various provinces are between 
medRxiv preprint doi: https://doi.org/10.1101/2020.09.04.20188235; this version posted September 9, 2020. The copyright holder for this preprint (which was not certified by peer review) is the author/funder, who has granted medRxiv a license to display the preprint in perpetuity.

All rights reserved. No reuse allowed without permission.

$1550-2.46 \%$ and $-8.57 \%-4.13 \%$, the errors are small and the fit is good, so the model is suitable. We

156 further analyzed the average relative error between the actual cases and the predicted values in

157 each province of the test group (June 1 - June 30, 2020). The results are shown in Table 2.

158

159 Table 2

160 the average relative error table of actual cumulative cases, deaths, recovery and fitted values in each province from

161 June 1 st to 30 th

\begin{tabular}{|c|c|c|c|}
\hline \multirow{3}{*}{ Province } & \multirow{3}{*}{$\begin{array}{l}\text { Cumulative cases } \\
\text { average relative error }\end{array}$} & \multirow{3}{*}{$\begin{array}{l}\text { Cumulative deaths } \\
\text { average relative error }\end{array}$} & \multirow{3}{*}{$\begin{array}{l}\text { Cumulative recovery } \\
\text { average relative error }\end{array}$} \\
\hline & & & \\
\hline & & & \\
\hline Beijing & $22.66 \%$ & $0.00 \%$ & $0.45 \%$ \\
\hline Shanghai & $3.00 \%$ & $-9.40 \%$ & $-0.50 \%$ \\
\hline Gansu & $6.47 \%$ & $0.00 \%$ & $0.66 \%$ \\
\hline Sichuan & $-21.32 \%$ & $-6.67 \%$ & $-0.34 \%$ \\
\hline Hebei & $2.76 \%$ & $0.00 \%$ & $0.60 \%$ \\
\hline Shaanxi & $-0.32 \%$ & $0.00 \%$ & $0.19 \%$ \\
\hline Guangdong & $0.44 \%$ & $0.00 \%$ & $1.16 \%$ \\
\hline Liaoning & $1.74 \%$ & $0.00 \%$ & $-0.98 \%$ \\
\hline Chongqing & $0.30 \%$ & $0.00 \%$ & $0.00 \%$ \\
\hline Fujian & $0.88 \%$ & $0.00 \%$ & $-2.07 \%$ \\
\hline Tianjin & $1.93 \%$ & $0.00 \%$ & $1.10 \%$ \\
\hline Jiangsu & $0.05 \%$ & $*$ & $0.26 \%$ \\
\hline Hubei & $0.56 \%$ & $0.08 \%$ & $0.05 \%$ \\
\hline
\end{tabular}


medRxiv preprint doi: https://doi.org/10.1101/2020.09.04.20188235; this version posted September 9, 2020. The copyright holder for this preprint (which was not certified by peer review) is the author/funder, who has granted medRxiv a license to display the preprint in perpetuity.

All rights reserved. No reuse allowed without permission.

\begin{tabular}{|c|c|c|c|}
\hline Zhejiang & $0.04 \%$ & $0.00 \%$ & $0.00 \%$ \\
\hline Henan & $0.00 \%$ & $0.00 \%$ & $-0.28 \%$ \\
\hline Hainan & $0.87 \%$ & $0.00 \%$ & $0.60 \%$ \\
\hline Heilongjiang & $0.21 \%$ & $-8.70 \%$ & $0.21 \%$ \\
\hline Jilin & $-0.15 \%$ & $0.00 \%$ & $-8.84 \%$ \\
\hline Hunan & $0.00 \%$ & $0.00 \%$ & $0.00 \%$ \\
\hline Shandong & $-1.30 \%$ & $0.00 \%$ & $0.35 \%$ \\
\hline Tibet & $0.00 \%$ & $*$ & $0.00 \%$ \\
\hline Guangxi & $-0.21 \%$ & $0.00 \%$ & $0.00 \%$ \\
\hline Shanxi & $0.00 \%$ & $*$ & $0.00 \%$ \\
\hline Ningxia & $0.00 \%$ & $*$ & $0.00 \%$ \\
\hline Xinjiang & $0.00 \%$ & $0.00 \%$ & $0.00 \%$ \\
\hline Jiangxi & $0.00 \%$ & $0.00 \%$ & $0.00 \%$ \\
\hline Guizhou & $0.00 \%$ & $0.00 \%$ & $0.00 \%$ \\
\hline Inner Mongolia & $-9.13 \%$ & $0.00 \%$ & $0.62 \%$ \\
\hline Anhui & $0.00 \%$ & $-9.52 \%$ & $0.00 \%$ \\
\hline Qinghai & $0.00 \%$ & $*$ & $0.00 \%$ \\
\hline Yunnan & $0.00 \%$ & $0.00 \%$ & $0.44 \%$ \\
\hline
\end{tabular}

164 It can be seen from Table 2 that the average relative errors of actual cumulative cases, deaths,

165 recovery and predicted values in each province are between $-22.32 \%-22.66 \%,-9.52 \%-0.08 \%$, 
$-8.84 \%-1.16 \%$. The results of comprehensive experimental group and test group show that the error between fitting and prediction is small, the fitting effect is good, the model supports and is suitable for epidemic situation prediction.

COVID-19 trend in mainland of China : According to each provincial model, we get the overall trend of COVID-19 in mainland of China, as shown in Fig.6. The trend of the fitting line between the predicted value and the actual value of the cumulative cases, deaths and recovery was consistent $(6 a, 6 b, 6 c)$. At the beginning of the epidemic, the cases showed an exponential upward trend. At the end of January, the Chinese government took measures to seal the city, isolate it from the source of infection, and reduce the possibility of infection, the epidemic was controlled in mainland of China. The epidemic situation in Hubei, Guangdong, Zhejiang, Henan and other places in mainland of China is relatively serious (6a). Residents in this area still need to do epidemic prevention and control work to prevent the possibility of a second rebound of the epidemic situation.

With the increase of confirmed cases, the number of deaths initially gradually increased. It can be seen from $6 \mathrm{~b}$ that the number of deaths in mid-April showed a linear upward trend. The reason for this data surge is that the preliminary data statistics are incomplete, the statistical standards are inconsistent and there are varying degrees of delay in the statistical process [9]. The state has proposed efforts to reduce deaths, requiring provinces to increase the number of ventilators to ensure adequate medical facilities. The number of deaths in mainland of China has remained stable around May. In this fight against the epidemic, many volunteers have appeared in many places, and medical personnel throughout the country have conducted targeted research on the epidemic, and their experience and level have been improved, resulting in the continuous 
medRxiv preprint doi: https://doi.org/10.1101/2020.09.04.20188235; this version posted September 9, 2020. The copyright holder for this preprint (which was not certified by peer review) is the author/funder, who has granted medRxiv a license to display the preprint in perpetuity.

All rights reserved. No reuse allowed without permission.

188

189

190

191

192

193 improvement of the number of cures (6c).

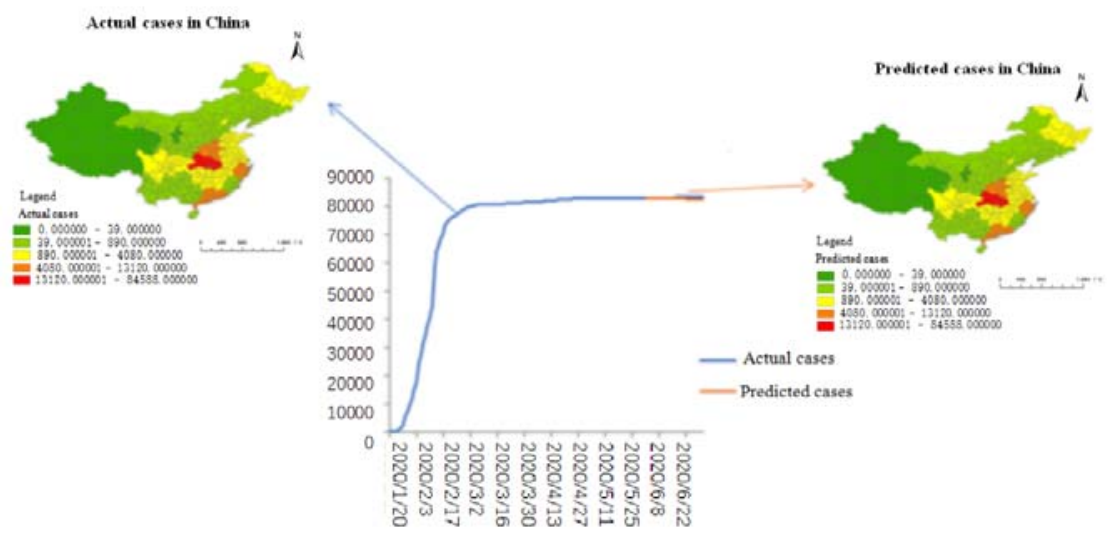

(a)

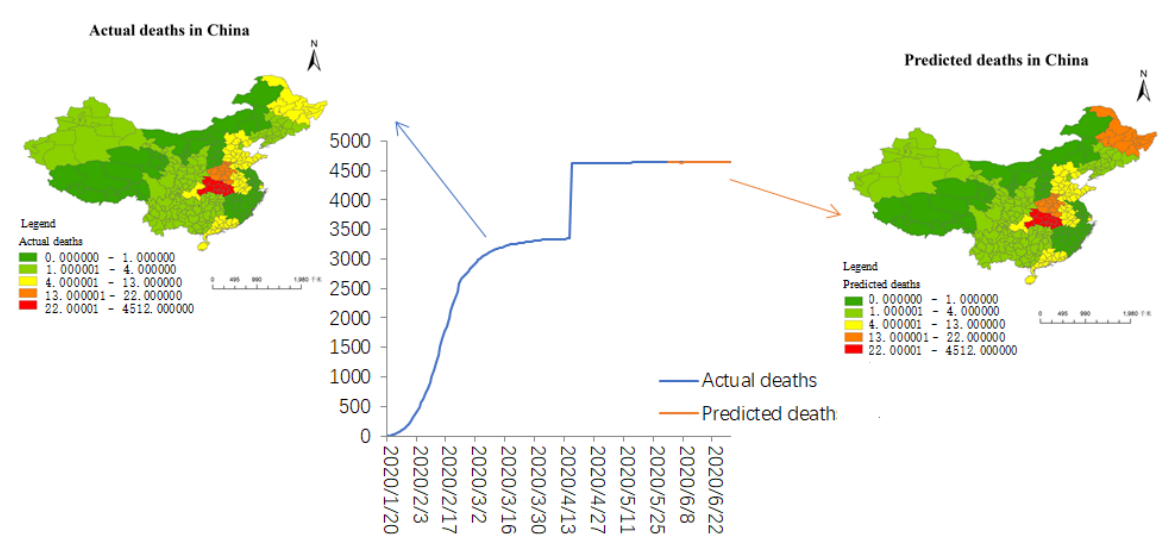

(b)

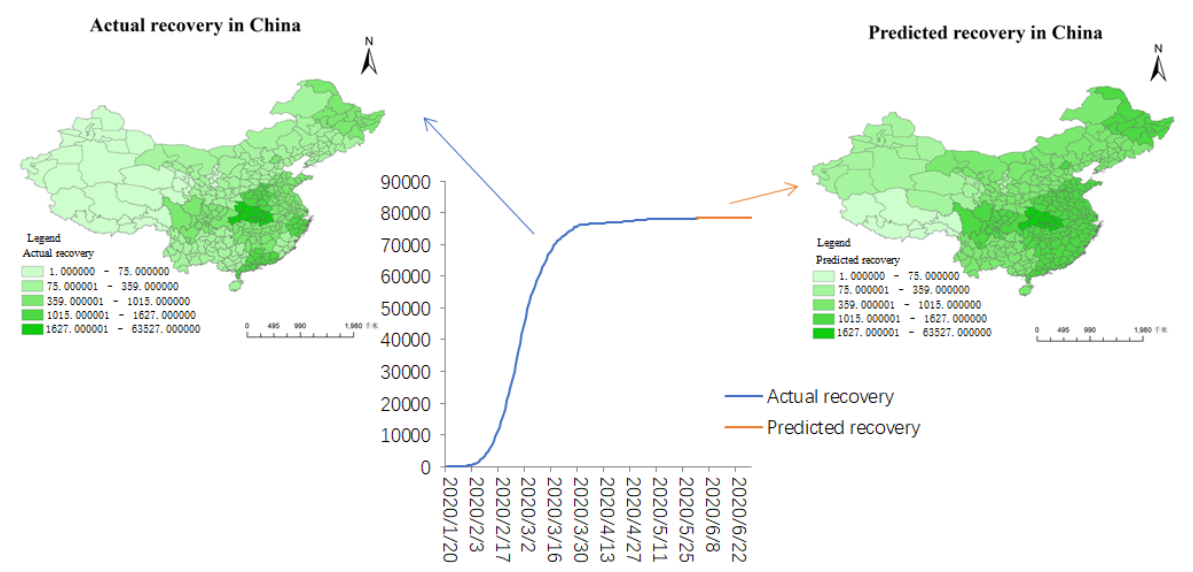

(c)

Fig.6 Cumulative cases, deaths, recovery figure in mainland of China 
197

198

199

200

201

202

203

204

205

\section{Discussion}

Data from January to June 2020 shows that the epidemic in mainland of China has peaked at the end of February and has been steadily declining since then. This is mainly due to the closed management measures taken by the Chinese government in the face of the COVID-19 pandemic to stop population-intensive Place, and achieved good results. By the end of March 2020, all regions had lifted the closure measures and adjusted the primary response to major public health emergencies to secondary, and the cases in the epidemic have not changed significantly since then.

This may be related to climate factors such as continuous temperature increase in various places.

The studies have shown that changes in temperature and humidity may be important factors affecting the spread of COVID-19[10].

In recent years, ARIMA model, neural network and so on are more active in the field of epidemic prediction because they can relatively accurately explore the occurrence and development of epidemics[11-15].

The reason why ARIMA model can be widely favored in the field of epidemiological prediction is that it not only absorbs the advantages of traditional regression analysis but also takes advantage of the moving average, and can affect many factors affecting the development of the epidemic (such as temperature, humidity, aerosol, population migration, etc.) integrated into time variables for quantitative expression, is a method with strong practicability and high prediction accuracy. However, ARIMA model also has certain limitations. It is a mathematical model built on past historical data. Therefore, ARIMA model is only suitable for short-term forecasting. If the forecasting time is too long, it will increase the forecasting error and affect the forecasting accuracy[16-18]. 

with multiple models.

\section{Conclusion} control in this region.

Funding: spatial data analysis and geoscientific calculation are used to study urban vulnerability 
242 Acknowledgements: This work was financially supported by spatial data analysis and

243 geoscientific calculation are used to study urban vulnerability based on microgeographic

244 units(grant numbers: 41461035). Thanks to the National and local health and construction commission for providing data on the daily cumulative cases, deaths and recovery.

Declaration of Interest Statement:No conflict of interest exits in the submission of this behalf of my co-authors that the work described was original research that has not been published authors listed have approved the manuscript that is enclosed.

\section{Reference}

255 1. Li Q, Guan X, Wu P, Wang X, Zhou L, Tong Y, et al. Early transmission dynamics in Wuhan,

2. Chen Y, Liu Q, Guo D. Emerging coronaviruses: Genome structure, replication, and 
medRxiv preprint doi: https://doi.org/10.1101/2020.09.04.20188235; this version posted September 9, 2020. The copyright holder for this preprint (which was not certified by peer review) is the author/funder, who has granted medRxiv a license to display the preprint in perpetuity.

All rights reserved. No reuse allowed without permission.

264

265

266

267

268

269

270

271

272

273

274

275 network (grnn) in forecasting hepatitis incidence in heng county, China. PLoS ONE 2016; doi:

10.1371/journal.pone.0156768

5. Liu L, Luan RS, Yin F, Zhu XP, Lü Q. Predicting the incidence of hand, foot and mouth disease in Sichuan province, China using the ARIMA model. Epidemiology and Infection 2016;doi: 10.1017/S0950268815001144

6. Huang L, Li XX, Abe EM, Xu L, Ruan Y, Cao CL, et al. Spatial-temporal analysis of pulmonary tuberculosis in the northeast of the Yunnan province, People's Republic of China. Infectious Diseases of Poverty 2017;doi: 10.1186/s40249-017-0268-4

7. Liu Q, Liu X, Jiang B, Yang W. Forecasting incidence of hemorrhagic fever with renal syndrome in China using ARIMA model. BMC Infectious Diseases 2011; doi:

$10.1186 / 1471-2334-11-218$

8. Niemann KO, Quinn G, Goodenough DG, Visintini F, Loos R. Addressing the effects of canopy structure on the remote sensing of foliar chemistry of a 3-dimensional, radiometrically porous surface. IEEE Journal of Selected Topics in Applied Earth Observations and Remote Sensing 2012;doi: 10.1109/JSTARS.2011.2179637

9. AHMADI, Mohsen, et al. Investigation of effective climatology parameters on COVID-19 outbreak in Iran. Science of The Total Environment, 2020,138705.https://doi.org/10.1016/j.scitotenv.2020.138705.

10 Ahmadi M, Sharifi A, Dorosti S, Jafarzadeh Ghoushchi S, Ghanbari N. Investigation of effective climatology parameters on COVID-19 outbreak in Iran. Science of the Total Environment 2020;doi: 10.1016/j.scitotenv.2020.138705

11. Wah W, Das S, Earnest A, Lim LKY, Chee CBE, Cook AR, et al. Time series analysis of 
medRxiv preprint doi: https://doi.org/10.1101/2020.09.04.20188235; this version posted September 9, 2020. The copyright holder for this preprint (which was not certified by peer review) is the author/funder, who has granted medRxiv a license to display the preprint in perpetuity.

All rights reserved. No reuse allowed without permission.

286

287

288

289

290

291

292

293

294

295

296

297

298

299

300

301

302

303

304

305

306

307

demographic and temporal trends of tuberculosis in Singapore. BMC Public Health 2014; doi:

$10.1186 / 1471-2458-14-1121$

12. Du Z, Xu L, Zhang W, Zhang D, Yu S, Hao Y. Predicting the hand, foot, and mouth disease incidence using search engine query data and climate variables: An ecological study in Guangdong, China. BMJ Open 2017;doi: 10.1136/bmjopen-2017-016263

13. Mollalo A, Mao L, Rashidi P, Glass GE. A gis-based artificial neural network model for spatial distribution of tuberculosis across the continental united states. International Journal of Environmental Research and Public Health 2019;doi: 10.3390/ijerph16010157

14. Zou JJ, Jiang GF, Xie XX, Huang J, Yang XB, Lu M. Application of a combined model with seasonal autoregressive integrated moving average and support vector regression in forecasting hand-foot-mouth disease incidence in Wuhan, China. Medicine (United States) 2019;doi:

10.1097/MD.0000000000014195

15. Li Z, Wang Z, Song H, Liu Q, He B, Shi P, et al. Application of a hybrid model in predicting the incidence of tuberculosis in a Chinese population. Infection and Drug Resistance 2019; doi: 10.2147/IDR.S190418

16. Wang Y wen, Shen Z zhou, Jiang Y. Comparison of ARIMA and GM(1,1) models for prediction of hepatitis B in China. PLoS ONE 2018;doi: 10.1371/journal.pone.0201987

17. Petukhova T, Ojkic D, McEwen B, Deardon R, Poljak Z. Assessment of autoregressive integrated moving average (ARIMA), generalized linear autoregressive moving average (GLARMA), and random forest (RF) time series regression models for predicting influenza A virus frequency in swine in Ontario, Canada. PLoS ONE 2018; doi:

10.1371/journal.pone.0198313 
medRxiv preprint doi: https://doi.org/10.1101/2020.09.04.20188235; this version posted September 9, 2020. The copyright holder for this preprint (which was not certified by peer review) is the author/funder, who has granted medRxiv a license to display the preprint in perpetuity.

All rights reserved. No reuse allowed without permission.

308

309

310

311

312

313

314

315

316

317

318

319

320

321

18. Jackson ML, Chung JR, Jackson LA, Phillips CH, Benoit J, Monto AS, et al. Influenza vaccine effectiveness in the United States during the 2015-2016 season. New England Journal of Medicine 2017;doi: 10.1056/NEJMoa1700153

19. Cai Y, Huang T, Liu X, Xu G. The effects of "Fangcang, Huoshenshan, and Leishenshan" hospitals and environmental factors on the mortality of COVID-19. PeerJ 2020; doi: $10.7717 /$ peerj.9578

20. C. Luo et al., Possible Transmission of Severe Acute Respiratory Syndrome Coronavirus 2 (SARS-CoV-2) in a Public Bath Center in Huai'an, Jiangsu Province, China. JAMA Netw Open 3, e204583

21. Lipsitch M. Seasonality of SARS-CoV-2: WIll COVID-19 go away on its own in warmer weather? Center for Communicable Disease Dynamics Harvard Blog 2020;doi:

10.1017/CBO9781107415324.004

22. Oliveiros B, Caramelo L, Ferreira NC, Caramelo F. Oliveiros et al 2020 Temperature and humidity in doubling time of cases. 2020. doi: 10.1101/2020.03.05.20031872 